\title{
Branded Marketing Events: Engaging Australian and French Wine Consumers
}

\begin{abstract}
:
Purpose - This paper introduces the term Branded Marketing Events (BMEs), and examines the role of its experiential components as a strategic tool for the facilitation of customer brand engagement. This study examines five experiential components of BMEs at events held in Australia and France to determine their respective impact on customer brand engagement.

Design/methodology/approach - Surveys were distributed to attendees of ten events by six wine brands in South Australia, and six events in five sub-regions of Bordeaux.

Findings - Findings suggest that BMEs influence customers’ brand engagement and brand purchase intention in both Australia and France. However, the experiential components within the events had differing effects. Australian customers were influenced by cognitive, sensorial, and relational experiences and their increased customer brand engagement strongly influenced brand purchase intention. French customers, however, required pragmatic event experiences to build brand engagement.
\end{abstract}

Originality/value - Recognizing their mutual experiential and interactive foundations, this study integrates the research domains of marketing events, customer experiences and customer brand engagement, and contributes to the strategic understanding of how branded event experiences facilitate customer brand engagement.

Keywords: Branded Marketing Events, Customer Brand Engagement, Customer Experience, Experiential Marketing, Wine Events

Article Type: Research Paper 


\section{Branded Marketing Events: Engaging Australian and French Wine Consumers}

\section{Introduction}

Marketing managers and event coordinators are increasingly sophisticated with their design of customer event experiences, often initiating events with the explicit purpose of creating interactive, brand-related experiences to facilitate customer engagement with the brand. This paper introduces the term Branded Marketing Events (BMEs) to reflect these types of events, designed for the express purpose of facilitating customer interaction and engagement with the brand. BMEs differ from traditional marketing events or sponsorship arrangements, where marketing has some application but is not the primary purpose of the event (Wood, 2009). In contrast, organizations create BMEs to initiate interaction and active engagement with customers with the primary objective of developing a deeper psychological connection with the brand (Crowther, 2011). BMEs provide a physical space for customers to experience a brand; hence five experiential components of the event are examined; cognitive, emotional, pragmatic and relational components (Chang and Chieng, 2006; Gentile et al., 2007). Despite extant literature examining these experiential components in the context of tangible product-related experiences (Brakus et al., 2009), experiential components have received less attention in an event context and little is known about how each component impacts on customer engagement with brands. This paper contributes to the understanding of BMEs through an investigation of the impact of each experiential component on customer brand engagement. It also aids in the understanding of customer brand engagement, as this paper investigates the role of event experiences as a strategic driver of this construct.

Despite the growing interest in customer brand engagement (Brodie et al., 2011; So et al., 2014b; Chandler and Lusch, 2015), research to date has predominantly focused on creating a common conceptualization of the construct (Brodie et al., 2011; Vivek et al., 2014), its 
behavioral manifestations (Jaakkola and Alexander, 2014) and its outcomes (So et al., 2014b). Further understanding of the strategic tools to facilitate customer brand engagement is required, with the investigation of different potential engagement opportunities, both online and offline, as well as different brand contexts. The growing trend of using events or activities to engage customers (Vivek et al., 2012) suggests this phenomenon warrants further research development. To explore the nomological network of customer brand engagement and develop an understanding of the interplay between event experiences and customer brand engagement, this study empirically investigates the influence of experiential event components within the Australian and French wine sectors.

While BMEs are increasingly utilized to facilitate customer brand engagement across a wide range of industries, an examination of customer experiences of brand-related events in the wine sector was considered particularly pertinent. The nature of the product itself, and the associated brand-related events, enables an examination of all of the experiential components proposed. Wine is a sensorial product, which is usually consumed in a social setting, and of which the technical complexities are often discussed among connoisseurs. These characteristics make the wine industry a particularly relevant context in which to investigate multisensory experiences (Charters et al., 2009). BMEs in this sector often leverage these characteristics and have a diverse mix of cognitive, emotional, sensorial, pragmatic, and relational components. The examination of this phenomenon across two leading wine industries, Australia and France, allows for a good diversity of event types, and also allows us to understand the contextual relevance of the impact of event experiences on customer brand engagement.

A key contribution of this paper is the investigation of customer experiences created through an event (BME), to identify how brands create unique experiences to facilitate customer brand engagement. The concept of BMEs is introduced to the literature on marketing events, with the express purpose of examining events developed to facilitate customer interaction with a 
brand and foster customer brand engagement. Having identified five experiential components in the consumer experience literature (Gentile et al., 2007), this paper investigates these components in the context of events and understands their brand-related impact on consumers.

This study extends the customer brand engagement literature as it further explores the nomological network of customer brand engagement and provides insight into the role of BMEs and customer experiences as antecedents to customer brand engagement. These relationships are examined in two countries, Australia and France, and suggest that the effectiveness of experiential components may be culturally determined. This paper brings together the constructs of customer experience, marketing events and customer brand engagement which share similarities in their conceptualization; specifically their emphasis on interaction (Whelan and Wohlfeil, 2006; Brodie et al., 2011), acknowledgment that customers are drivers of value (Close et al., 2006; Calder et al., 2013), and recognition of the importance of experience in facilitating brand outcomes (Crowther, 2010; Vivek et al., 2012).

The remainder of this paper is structured with a review of the extant literature on marketing events, customer experience and customer brand engagement. Research hypotheses and a conceptual framework are then presented. The method section identifies the research approach, measurement items, and reports on the robustness of the data collected. Findings from the Australian and French samples are discussed in the results section, as well as a comparison of the models resulting from the two data sets using multi-group analysis. The paper concludes with general discussion, managerial implications and limitations of the study.

\section{Branded Marketing Events}

The foundation for the concept of Branded Marketing Events (BMEs) lies within the marketing events literature (Whelan and Wohlfeil, 2006; Drengner et al., 2008) and draws 
from the broader literature area of customer experience (Gentile et al., 2007; Brakus et al., 2009). There is considerable debate among scholars regarding the conceptualisation and definition of marketing events (Close et al., 2006; Wohlfeil and Whelan, 2006; Drengner et al., 2008; Wood, 2009). A sponsorship agreement entitles the sponsoring brand to associate with an event (Drengner et al., 2008); the sponsorship event is not created for the purpose of communicating brand information or facilitation of customer-brand interaction. Due to this lack of emphasis and the focus on the event itself, not the sponsor, customers at sponsorship events may or may not interact with the brand in the event space (Drengner et al., 2008). The sponsoring brand generally lacks control over event operations and distribution of brandrelated information (Mau et al., 2006; Drengner et al., 2008). Multiple brands can sponsor the same event, often to the detriment of each sponsor, as the event becomes cluttered with conflicting brand messages (Wood, 2009). This results in a reduced ability for the event to translate to brand-related outcomes for the sponsoring brand.

In contrast, marketing events, or promotional events, are created specifically for the purpose of marketing a brand (Wood, 2009). The brand is the central focus and the event can be tailored to emphasize brand-related information and encourage customer-brand interaction (Wood, 2009). The host brand of a marketing event maintains control over the marketing dialogue and event operations. The differing attributes and subsequent brand outcomes are demonstrated in Mau et al., (2006), who conclude that sponsored events and marketing events are not only different activities, but that marketing events have the ability to be more effective in influencing customer attitudes. The literature is clear that sponsorship and marketing events are separate activities; sponsorship should not be considered within the definition of marketing events (Wood, 2009).

This paper introduces the term, branded marketing events, to suggest a marketing event that is brand focused and encourages interaction between the consumer and the brand. 
Traditional marketing event literature reflects a goods-dominant lexicon rather than a servicedominant approach and considers the marketing event as a communication tool (Drengner et al., 2008; Leischnig et al., 2011) that promotes or communicates to customers (Gupta, 2003; Close et al., 2006), implying one-way communication. This paper builds on the marketing events literature (Whelan and Wohlfeil, 2006; Drengner et al., 2008) and the customer experience literature (Gentile et al., 2007; Brakus et al., 2009) and captures the nature of dynamic interactions and hence recognises the principles of service dominant logic (Vargo and Lusch, 2008) and customer engagement (Brodie et al., 2013). As such, we define Branded Marketing Events (BMEs) as a brand-initiated experience that serves as an opportunity for customers to interact with the brand and other actors.This more clearly positions the event as a branding activity; it is brand-centric, with the intention of eliciting brand-related outcomes such as customer brand engagement.

Our definition of a 'branded marketing event' recognizes the necessity for customers to interact with the brand at the event, and is operationalized through a consideration of the key aspects of a customer experience. Previous studies investigating customer experience have typically examined product-related experiences (Gentile et al., 2007) or with reference to experiential (product) brands (Brakus et al., 2009). It is widely recognized that an event falls within the plethora of customer experiences (Schmitt, 1999; Gentile et al., 2007), and as such customer experience measures are utilized to capture a BME experience. This paper uses the experiential components indicated in these studies to measure the types of experiences initiated during a BME. The measure developed by Gentile et al. (2007) was identified as an appropriate conceptual and empirical frame as it provides a good depiction of social elements (Schmitt, 1999), as well as cognitive aspects (Brakus et al., 2009).

Five components of the customer experience were incorporated in this study; cognitive, emotional, sensorial, pragmatic, and relational (Gentile et al., 2007). A cognitive experience is 
one that requires the participant to actively think, or aims to stimulate thought or conscious mental processes in a particular area of interest or knowledge (Gentile et al., 2007). An emotional experience evokes an affective response and targets moods, feelings and/or emotions (Gentile et al., 2007). A sensorial experience provides positive sensory stimulation, addressing sight, hearing, touch, taste and/or smell (Gentile et al., 2007). A pragmatic experience requires physical behaviors or actions from the customer, and a relational experience emphasizes the social context and relationships with others (Gentile et al., 2007). A single event may contain one, multiple or all experiential components to varying degrees. Table 1 outlines the definitions of each experiential component, and identifies examples of winery BMEs that demonstrate these components.

[INSERT TABLE 1 ABOUT HERE]

\section{BMEs and Customer Brand Engagement}

Customer Brand Engagement is defined as “the intensity of an individual’s participation in and connection with an organization's offerings and/ or organizational activities, which either the customer or the organization initiate” (Vivek et al., 2012, p. 127). This definition of customer brand engagement recognizes that either the customer or the provider (the wine brand) initiates engagement, and it highlights the need for an interaction between the focal object (i.e. the brand) and the customer. In this regard, customer brand engagement occurs from the connection that individuals form with the brand based on their experiences at the BME (Vivek et al., 2012). Although Vivek et al. (2012) recognize that providers may initiate activities or events to engage customers they do not explain how the nature of interaction with the event facilitates customer brand engagement. 
Customer brand engagement is most commonly conceptualized as a state of activation with cognitive, affective, and behavioral elements (Hollebeek, 2011b). It is a heightened-state of connectedness with a brand, where customers are motivated to interact with the brand, create value, and develop strong brand connections (Brodie et al., 2013). In contrast, brand experience is an internal and behavioral response from an individual resulting from brandrelated stimuli (Brakus et al., 2009). Brand experience does not presume a motivational state, which distinguishes it from customer engagement (Hollebeek, 2011a); it can include experiences in which the consumer shows little interest or connection with the brand (Brakus et al., 2009).

Examining BMEs from an engagement perspective, wineries must not only focus on facilitating an experience, they must ensure that this experience elicits a heightened psychological state for the customer, in order for it to be truly effective. Therefore, the key driver of the success of a BME lies in activities that create customer brand engagement. A customer who participates at a BME will demonstrate engagement when they interact with other attendees, receive experiential cues within the BME (music, food, and tastings) and/or communicate with winery sales or event staff. Through interacting within the experiential event, they create an experience that is of relevance to them, and therefore gain the most value from the experience; customers interact with the brand and with other customers, they are not passive during the experience. Firms provide a platform through which customers create their own unique value in the experience (Brodie et al., 2011). The constitution of this event should be determined with careful consideration of the nature of experiences that facilitate customer brand engagement. Therefore, there is a need to understand which experiences drive Australian and French wine customers to engage with the respective brands in each country. 


\section{The Australian and French Wine Context}

The French and Australian wine industries have long been considered two of the dominant global wine centers; the first regarded as the home of 'Old World wine', rich in wine history and tradition, and the second a rapidly expanding 'New World wine’ country (Anderson, 2004). As a result, France and Australia are a common choice for cross-cultural wine research (e.g. Lockshin et al., 2001; Jordan et al., 2007; Lereboullet et al., 2013). France has long been the largest producer and consumer of wine worldwide (OIV, 2014), however, wine production and consumption is gradually declining in France, as it is throughout Europe (Karlsson and Karlsson, 2015). In contrast, wine consumption in Australia has increased in recent decades rising from 12 per cent of the nations alcohol consumption to 38 per cent in the last 50 years (Germov and McIntyre, 2013), and Australia is now the $7^{\text {th }}$ largest producer and $8^{\text {th }}$ largest consumer of wine worldwide (OIV, 2014).

The difference between the Australian and French wine industries is well recognized, particularly in regards to their wine consumer culture and wine industry structures. Australian wine consumer culture is still developing; as wine consumption and wine tourism is growing in Australia, as is the level of 'wine interested' consumers and their need for wine knowledge (Charters and Ali-Knight, 2000). Australian wine consumers are more desirous of wine knowledge and are willing to acquire it, even at a cost (Ogbeide et al., 2014). French wine culture, conversely, is rich in history and deeply embedded within general French culture (Summerfield, 2013; Overby et al., 2004). The Australian wine industry is dominated by a small number of large wineries (accounting for over $90 \%$ of the market); with over two thousand small wineries competing for the remaining share (Winebiz, 2013). While wine regions in Australia carry some importance, the customer associates predominantly with the individual wine brand (Rasmussen and Lockshin, 1999). In contrast, the French wine sector contains more than three hundred wine appellations (FranceAgriMer, 2013) and about fifteen wine regions that 
include thousands of small wineries. The complexity of this structure explains why the wine estate is considered as the home of the brand (Bouzdine-Chameeva et al., 2013). French consumers do not generally identify with individual wineries, but more with wine regions (e.g. Bordeaux, Alsace or Champagne) or wine growing areas within these regions (e.g. SaintEmilion or Medoc in the Bordeaux wine region) (Mora and Moscarola, 2010). Hence, the investigation of customer brand engagement across these two distinct wine cultures provides a unique insight into how branded marketing event experiences vary for different consumers.

Even with these cultural and industry differences, wine events are common in both countries (Hall et al., 2009). Wine events have grown exponentially in Australia since the 1980s, both at a wine region and individual winery level (Hoffman et al., 2001). Particularly in wine marketing, any new activity should be tested for its feasibility before expanding into a new country, as some consumer motives are common across cultures while others are not (Hall et al., 1997). This provides an opportunity to investigate the phenomenon of BME experiences and their impact on customer brand engagement in two disparate marketing and cultural environments. In considering the impact of BMEs, it is important to investigate whether the BME experience impacts on Australian and French customers in the same way. Given the differences in how customers identify with a brand, and their likely knowledge of wine, it is important to investigate whether customer brand engagement is facilitated in a similar manner.

\section{Conceptual Framework and Hypotheses Development}

An 'experience' is recognized as an “environment in which the brand is marketed or sold (e.g. events)” (Brakus et al., 2009, p. 53). While extant literature recognizes that customers engage with the event itself (Vivek et al., 2012), it is the interaction with the brand within the event space that facilitates customer brand engagement. This is also one of the key features behind the definition of a BME as opposed to a sponsored event; BMEs elicit active engagement between the customer and the brand through an experiential approach. Previous 
research on marketing events has overlooked the active participation of the target group in the communication of the marketing message (Drengner et al., 2008). However, BMEs are an effective platform for a company to interact with customers, engage them, and create value in the experience with them. Therefore, this relationship requires further investigation.

The following section identifies the ability for the cognitive, emotional, sensorial, pragmatic and relational experiential components to each contribute to customer brand engagement.

A cognitive experience is one that requires the participant to actively think, or aims to stimulate thought or conscious mental processes on a particular area of interest or knowledge (Gentile et al., 2007). Individuals have a desire to continuously learn about a variety of topics of interest to them, and therefore have a willingness to engage in experiences where they can gain information and develop ideas (Packer and Ballantyne, 2004, p. 54). The sharing of information gives the attendee a greater knowledge on a particular topic of interest, and creates a closer connection with the brand. For example, the 'wine connoisseur' actively seeks information about wine brands, regions, varietals, production processes; events that provide in-depth information are of great interest to these customers. The intrigue and stimulation created through a cognitive experience will encourage the customer to interact more with the brand and create a greater sense of customer brand engagement. Therefore the following hypotheses are proposed;

H1a: Cognitive experience is positively related to the Australian customer's brand engagement

H1b: Cognitive experience is positively related to the French customer’s brand engagement 
An emotional experience evokes an emotional response such as a change in moods, feelings and/or emotions (Gentile et al., 2007). Attendees within this experience feel a strong connection with the brand due to the excitement, novelty, or emotional atmosphere created. BMEs with a predominantly emotional component are anticipated to create a closer connection between customers and the brand, as a result of their interaction with the brand at the BME, and stronger identification with the brand (Wohlfeil and Whelan, 2006). Experiences that are predominantly emotional or entertaining in nature will appeal to attendees' moods and create a level of excitement, encouraging them to become completely engrossed in the brand. In addition, this excitement and enthusiasm will encourage them to interact and think further about the brand, deepening the sense of engagement. Emotional experiences can also promote brand engagement if the experience reflects or embodies the image of the brand (Drengner et al., 2008). Therefore the following hypotheses are proposed;

H2a: Emotional experience is positively related to the Australian customer's brand engagement

H2b: Emotional experience is positively related to the French customer's brand engagement

A sensorial experience is one that provides positive sensory stimulation, addressing sight, hearing, touch, taste and/or smell (Gentile et al., 2007). Customers engage in experiences that heighten particular senses, and by its very nature customers must actively participate in the experience. Wine consumption is strongly related to leisure activity and aesthetic consumption (Charters and Pettigrew, 2005), in particular music and food. Events that include activities such as wine and food pairing, or tasting wines while listening to live music, can create a powerful and memorable experience and encourage customers to interact and engage with the brand. Therefore the following hypotheses are proposed; 
H3a: Sensorial experience is positively related to the Australian customer's brand engagement

H3b: Sensorial experience is positively related to the French customer's brand engagement

A pragmatic experience requires physical behaviors or actions from the customer (Gentile et al., 2007). The experience can include cognitive or emotional elements; however, the emphasis is on the active participation of the customer in the experience (Pine and Gilmore, 1998, p. 102). In the wine industry, many wineries invite their customers to participate in certain production processes, to provide them with a closer connection to the wine and how it is made (e.g. winery tours, wine stomping, or customers making their own individual wine blend). The physical, 'hands on' nature of the experience immerses the customer in the event experience. It is therefore expected that a pragmatic experience will draw great attention or aim to showcase the brand, contributing to customer brand engagement. Therefore the following hypotheses are proposed;

H4a: Pragmatic experience is positively related to the Australian customer's brand engagement

H4b: Pragmatic experience is positively related to the French customer's brand engagement

A relational experience is one that emphasizes the social context, relationships with others, or expression of one’s ‘ideal self’ (Gentile et al., 2007). Events are usually public and attended by many people, and so the entire experience occurs within a social context (Zhang et al., 2010). Relational experiences have the capacity to facilitate event engagement as customers receive considerable benefit from personal exchanges with other customers. Strategic BME organizers utilize this social setting to ensure that customers' interaction with the brand enables them to look good in front of their peers. This has an impact on the customer's motivation to further engage, 
interacting and being more engaged with the brand as a result. Wine consumption is commonly associated with a social experience, and in particular wine events are usually held within in a social setting. People often attend wine-related BMEs with others, for example friends, family or acquaintances, and enjoy interacting with likeminded others who have an interest in the winerelated lifestyle. The interactions with other customers or brand-representatives (e.g. the winemaker) may evoke pleasure in the customer. Therefore, the following hypotheses are proposed;

H5a: Relational experience is positively related to the Australian customer's brand engagement

H5b: Relational experience is positively related to the French customer’s brand engagement

Research on customer brand engagement has investigated various outcomes, including satisfaction, loyalty, commitment and trust (Brodie et al., 2013), brand usage intent (Hollebeek et al., 2014) and behavioral intention of loyalty (So et al., 2014a). Similar outcomes are identified in customer experience literature, including loyalty intentions and customer satisfaction (Klaus and Maklan, 2013) as well as word of mouth (Grewal et al., 2009) and purchase intentions (Palmer, 2010). It is important to investigate the anticipated brand-related outcomes resulting from customer brand engagement, particularly as a BME is an engagement activity that does not necessarily stimulate an immediate monetary outcome for the brand. Given that organizing a BME is often a considerable investment (in time and/or money) for the host brand, it is important to determine what outcomes are expected for the company. Therefore, the relationships between customer brand engagement and purchase intention are presented in this paper as confirmatory hypotheses: 
H6a: The Australian customers' brand engagement is positively related with their purchase intention with respect to the brand

H6b: The French customers' brand engagement is positively related with their purchase intention with respect to the brand

[INSERT FIGURE 1 ABOUT HERE]

\section{Method}

\section{Data Collection}

Wineries in South Australia, Australia and Bordeaux, France that conducted BMEs were invited to participate in the study. Participating wineries were selected to ensure a diversity of event experiences (e.g. wine tastings and tours, concerts in wine cellars, degustation and gastronomic dinners, exhibitions, educational and/or social events). It should be noted that each experiential component of the BME is not mutually exclusive; one event includes all of the different experiential components but to differing degrees, and this perception is derived from the individual (Gentile et al., 2007). Therefore, the researcher did not delineate the 'type' of event experience; the questionnaire included all five dimensions of experience for all types of events, and respondents self-reported on their perceptions on these dimensions.

Ten events held in South Australia by six wine brands were included in the study, while in Bordeaux the data collection process embraced wine estates located in five sub-regions (Saint-Emilion, Saint Julien, Entre-deux-Mers, Sauternes, and Graves). An outline of event types is provided in Table 2. 


\section{[INSERT TABLE 2 HERE]}

A pre-test of the questionnaire was first conducted with 220 current and prospective students attending events at an Australian university. This was an appropriate context to pretest the survey, as it was another example of a branded marketing event. All respondents had taken part in Open Day events, where they experienced social (e.g. barbecues) and intellectual activities (e.g. lectures) consistent with the brand experience of attending university. Student samples are often argued to lack generalizability; however, when they encompass an applicable population of interest or share a theoretically relevant commonality student samples are considered appropriate (Randall and Gibson, 1990). The focus of this study was to capture the experiences and perceptions of event attendees, and as the student sample had all attended a University event, they were deemed an appropriate study sample. All measured were found to be reliable and valid during this pre-test, so the researchers proceeded to the main study.

The main data collection used the same survey structure and included minor wording adaptations specific to each event name and wine brand or wine region. To reflect the customer's understanding of the brand in each cultural context, Australian consumers were asked to respond with respect to their engagement with the individual wine brand hosting the event (e.g. Wirra Vineyard) and French consumers were asked to respond with respect to the region/sub-region wine brand organizing the event (e.g. Saint-Emilion). The questionnaire was translated to French for the Bordeaux study and back translated to English to check for consistency of wording.

Each survey participant was asked about a single wine event they had attended. Specific details of the event including name, location, wine brand and date were referenced 
throughout the survey to ensure respondents answered the questions about that specific individual event. Researchers attended the events; in South Australia, the researcher asked event attendees for their email address to send a survey online; in Bordeaux, event attendees completed the survey during or immediately after the event through printed surveys. Online, post event surveys (e.g. Woisetschläger and Michaelis, 2012) were the preferred method of data collection in Australia, as the participating wineries requested that attendees be disturbed as little as possible during the event, and this method was considered convenient for the participants to complete the survey in their own time (Neuman, 2006). Conversely, printed surveys collected during the event (e.g. Close et al., 2006; Leischnig et al., 2011) were preferred data collection method in France, as French attendees were more likely to participate in the survey during the event (Velikova et al., 2015). This mixed data collection approach is consistent with previous cross-cultural research in the wine sector, which has utilized both online and printed survey methods to account for cultural preferences, situational differences, and to optimize the response rate in each country (e.g. Velikova et al., 2015). In total, 274 completed surveys were collected in Adelaide and 177 completed surveys in Bordeaux.

\section{Measurement}

All constructs were captured as multi-item variables (outlined in Table 3) including measures of cognitive, emotional, sensorial, pragmatic, and relational experiential components (Sweeney and Soutar, 2001; Chang and Chieng, 2006). The experiential components are reflective measures, as per their original development in Chang and Chieng, (2006). Only three dimensions of the So et al. (2014a) measurement model were utilized (cognitive, emotional and behavioral dimensions), consistent with the predominant paradigm in the extant customer engagement literature (Brodie et al., 2011). The behavioral 
engagement construct was further adapted with reference to Chan et al. (2010) to adequately reflect the nature of customer interactions and participation with the wine brands involved in the study. Purchase intention (So et al., 2014a) was utilized as a brand-related outcome measure. Minor modifications were made to existing scales to create linguistic style consistency and ensure their applicability to the new research context (Brakus et al., 2009), while still maintaining their original meaning. All of the items in each scale were utilized in the survey.

To ensure reliability and validity of the multi-item constructs, one-factor congeneric measurement models were tested for validity using AMOS 21 prior to the evaluation of a comprehensive measurement model $\left(\chi^{2}=350.56, \mathrm{df}=114, \mathrm{GFI}=0.92 ; \mathrm{CFI}=0.94, \mathrm{NFI}=\right.$ 0.92 , SRMR $=0.05$ ). Any items with factor loadings below 0.70 were removed, as this indicated poor fit with the latent construct (Byrne, 2010). In addition, items that had significant cross loadings were also removed to ensure good discriminant validity between the constructs. This resulted in the final cognitive experience, emotional experience, and brand purchase intention constructs each containing two items. Although it is the general convention to include at least three items in a construct, each of the two-item measures demonstrated construct reliability and validity and is therefore deemed an acceptable measure of the construct (Peter, 1981; Plewa et al., 2015). All latent constructs demonstrated composite reliability scores of at least 0.75 (Fornell and Larcker, 1981). Convergent validity was confirmed with the average variance extracted exceeding 0.5 and discriminant validity was examined with all average variance extracted (AVE) scores exceeding the square of the correlations between constructs (Fornell and Larcker, 1981; Hair et al., 2012). All final measurement items, their descriptive results and reliability and validity measures, are presented in Table 3. 


\section{[INSERT TABLE 3 HERE]}

Composites were computed for each construct for further analysis using a three-step approach (Rowe, 2002; Plewa et al., 2015). After testing one-factor congeneric measurement models for all multi-item constructs (step one), factor score regression weights provided by AMOS 21 were used to create a proportionally weighted scale score for every item (step two). The final composite scores were then computed in SPSS 21 (step three) as each proportionally weighted scale score was multiplied by the data column of the respective item (Rowe, 2002; Plewa et al., 2015). Customer brand engagement was calculated as a secondorder construct to remain consistent with its original development in So et al., (2014a), who argued that this method provided superior predictive validity of the construct.

Multi-group path analysis was employed to test for differences between the Australian and French data. Invariance testing employing a Chi-Square Difference $\left(\Delta \chi^{2}\right)$ test allowed for the identification of variations between values of model parameters across groups (Kline, 2005). To elaborate further on these differences, the model was estimated for each group separately and compared the respective regression weights.

\section{Results and Discussion}

To further explore the influence of BME experiences on customer brand engagement, the interrelationships between the factors were tested by means of a path model. The complete path model was tested using AMOS 21, and achieved fit $\left(\chi^{2}=28.4, \mathrm{df}=10, \mathrm{GFI}=0.98\right.$; $\mathrm{CFI}=$ 0.98, NFI $=0.96, \mathrm{SRMR}=0.01)$. A multi-group analysis was conducted to investigate the independent results of the Australian and French respondents.

\section{Australian Results}


For the Australian data, the standardized path estimates suggest the strongest impact of event experiences is the relationship between cognitive experience and customer brand engagement (0.29), followed by sensorial experience $(0.20)$ and relational experience $(0.12)$. Emotional experience and pragmatic experience were not significant factors to achieve engagement. These results provide support for hypotheses H1a, H3a and H5a, while H2a and H4a are not supported (see Table 4). The path model shows a strong relationship between customer brand engagement and brand purchase intention (0.74), indicating that Australian customers could be influenced by an engaging event experience (supporting H6a).

Overall, the preliminary findings suggest that cognitive, sensorial, and relational experiences have more influence on brand engagement of Australian customers. These experiences drive the customer to interact and engage with the brand in this event space. Facilitation of engagement is important to Australian customers at BMEs, as an engaging event is likely to increase brand purchase intention.

\section{[INSERT TABLE 4 ABOUT HERE]}

\section{French Results}

For the French data, the standardized path estimates indicate the strongest relationship between pragmatic experience and customer brand engagement (0.28). The path model shows a significant relationship between customer brand engagement and brand purchase intention (0.42), indicating that French customers are influenced by an engaging event experience. These results provide preliminary support for hypotheses $\mathrm{H} 4 \mathrm{~b}$ and $\mathrm{H} 6 \mathrm{~b}$, while $\mathrm{H} 1 \mathrm{~b}, \mathrm{H} 2 \mathrm{~b}, \mathrm{H} 3 \mathrm{~b}$ and H5b are not supported (see Table 5). 
These findings suggest that French customers engage with the brand primarily if they have participated in a pragmatic, or physical, experience. Surprisingly, there was no evidence that French consumers respond to experiences that are cognitive, emotional, sensorial, or relational in nature. These findings possibly reflect the cultural context of the study, with French customers having an established deep, cultural connection with their wine brands and possibly needing more physically interactive experiences to facilitate further brand engagement. While engaging with a branded marketing event elicits positive brand purchase intention, this outcome is not as strong for French customers in comparison to Australian customers.

\section{[INSERT TABLE 5 ABOUT HERE]}

\section{Model Comparisons}

A Chi-Square Difference $\left(\Delta \chi^{2}\right)$ test (Kline, 2005) reported a significant difference between the French and Australian data $\left(\Delta \chi^{2}=37.75, \Delta d f=6, p=0.00\right)$. To elaborate further on these differences, the model for each group is estimated separately and the respective regression weights are compared (see Table 6).

\section{[INSERT TABLE 6 ABOUT HERE]}

The results suggest that the influence of BMEs on customer brand engagement is distinct for Australian and French consumers. The findings provide a preliminary indication that the relative impact of each experiential component is culturally bound. 
The first set of hypotheses consider the impact of cognitive experience on brand engagement in Australia (H1a) and France (H1b). While a cognitive experience is among the most significant drivers of customer brand engagement for Australian customers, it is not significant for French customers; the model comparison reveals a significant difference between the effects of cognitive experience across the two cultural groups.

The cognitive component of a BME experience encompasses learning, cognitive processing and experiences providing mental stimulation for the participant (Gentile et al., 2007). A common example of a cognitive BME experience is a wine education session. As wine consumer culture develops in Australia, the level of 'wine interested' consumers increases (Charters and Ali-Knight, 2000). These consumers have a need for wine knowledge and therefore derive value in a cognitive experience that teaches them about wine. Australian attendees of a cognitive BME experience have a higher propensity to seek brand information, learn more about the brand, and facilitate discussions regarding the brand, hence exhibiting customer brand engagement (Hollebeek, 2011b; So et al., 2014a). Conversely, French customers, who are generally considered 'highly interested' wine consumers given their strong wine consumer culture (Summerfield, 2013) are more likely to have prior knowledge or experience with wine and therefore do not place the same level of importance in learning more about wine (Charters and Ali-Knight, 2000). Learning experiences can have greater value for customers who are 'interested' in wine, more so than customers who are 'highly interested' (Charters and Ali-Knight, 2000). As a result, cognitive experiences do not drive French customers to engage with the brand.

Findings indicate that the emotional component of experience does not facilitate customer brand engagement for Australian (H2a) or French consumers (H2b). This is an unexpected and important finding as the emotional nature of event experiences is a strong focus of marketing event literature (Packer and Ballantyne, 2004; Whelan and Wohlfeil, 
2006; Leischnig et al., 2011). However, in the context of this study the emotional experiences may create pleasant experiences or feelings of excitement among customers but not necessarily evoke a desire to interact with the brand (Pine and Gilmore, 1998; Yuan and Wu, 2008). Customers can enjoy an emotional BME experience while remaining passive in that experience. It should be noted that in this study emotional event experiences were examined in conjunction with other dimensions of a brand experience, and therefore the cut-through of the emotional experience may have been negated by other experiences.

Sensorial experience is the most significant driver of customer brand engagement among Australian customers (H3a), however, it is not significant for French customers (H3b), and there is a significant difference between these effects across the two groups. A sensorial experience provides sensory meaning and stimulation for customers (Schmitt, 1999), for example a wine and food pairing event. Focal to a sensory experience is sensory stimulation (Gentile et al., 2007), which inherently requires customer participation and heightened interaction in the event activities (Mollen and Wilson, 2010). Wine has a strong connection with aesthetic consumption (Charters and Pettigrew, 2005), and therefore wine events with a sensorial focus were predicted heighten the customer's excitement and event enthusiasm through aesthetics (Schmitt, 1999; So et al., 2014a). While it was predicted that French consumers would be stimulated through the aesthetics of the sensorial characteristics of wine events, the common acceptance of a wine culture may mean that this sensorial experience is regularly encountered and not sufficient to facilitate brand engagement.

While pragmatic experiences facilitate customer brand engagement for French customers (H4b), it has a non-significant effect for Australian customers (H4a), again showing a significant difference across the two groups. A pragmatic experience requires physical behaviors or actions from the customer (Gentile et al., 2007), and is expected to stimulate customer event engagement through the active customer participation inherent in the 
experience (Mollen and Wilson, 2010). As an example, a wine-blending event requires the customers to participate in the wine production process and their engagement is apparent from their considerable interaction effort elicited toward the activity (Hollebeek, 2011b), and their heightened level of attention given to the activity (Pine and Gilmore, 1998). Given the general acceptance of wine in the everyday culture in France, events that require physical interaction appear to be required to stimulate active participation and gain engagement with the consumers. Although French consumers are highly interested in wine consumption (Charters and AliKnight, 2000), initial indications are that they are not overtly engaged with wine brands and therefore a highly interactive experience is required to facilitate this.

Relational experience, while significant for Australian customers (H5a) and nonsignificant for French customers (H5b), was not found to differ at a 5\% level of significance across the two groups. A relational experience, for example wine dinner events or meeting the winemaker, is designed to be experienced with other people (Gentile et al., 2007). Relational experiences therefore appeal to customers through event enthusiasm (Vivek et al., 2012), and is argued to facilitate customer engagement. However, relational experiences also require attention and interaction to be directed towards another individual therefore taking the focus off the brand. Therefore, although it is proposed that the positive experience will transfer to the brand, there is a risk that this association will be indirect and weak. Findings in an Australian context suggest a weak relationship between the relational experience and the customer brand engagement. In France, where perhaps the wine consumer culture fosters lower engagement levels with the brand, the association is non-significant.

While the results found that customer brand engagement significantly impacted on brand purchase intention in both Australia (H6a) and France (H6b), the strength of the relationship was greater in Australia (0.74 compared with 0.42). The customer interacts with the brand and creates value during the event experience, hence fostering a positive feeling 
and predisposition towards the brand. This is consistent with previous research into marketing events that advocate that brand-related outcomes are a direct result of brand attitudes created at events (Martensen et al., 2007). Although brand engagement is conducive to future purchase intentions in both markets, it appears more important for Australian wine producers than French wine producers to focus on customer brand engagement as a pathway to future sales. This is consistent with the differences in wine consumer culture discussed.

\section{Conclusion}

\section{Theoretical Implications}

This paper introduces the notion of a branded marketing event (BME), which extends the marketing event literature to capture an event designed for the specific purpose of a consumer being able to interact with the brand. As such the operationalization of this construct draws from the customer experience literature and comprises of cognitive, emotional, sensorial, pragmatic and relational experiences (Gentile et al., 2007). This paper applies the concept of a BME to the wine industry; however, the concept is applicable in many other industries. The retail sector has many BMEs such as fashion shows, opening events, and specialty in-store events; BMEs in the retail sector continue to expand as retailers realize the importance of creating unique customer experiences in store (Leischnig et al., 2011). The education sector has Open Days, school tours, public lectures, and social events that showcase their brand and allow future student interaction. The hospitality and tourism sector often holds information sessions, events such as dinners and charity auctions, vintage celebrations as well as special events related to music, culture, and art that allow consumers to interact with the brand. Further application and investigation of the BME concept across multiple sectors is encouraged. 
The results of this study provide initial evidence that BMEs facilitate customer brand engagement. The ability of an event to initiate a meaningful and unique experience for the attendee leads them to enter a state of increased engagement with the brand. An association between BMEs and customer brand engagement is discussed in previous literature, however with little empirical support (Calder et al., 2009; Vivek et al., 2012). This study utilized five experiential components and investigated their impact on customer brand engagement. This conceptualization of experiential components has not been previously investigated in an event context and is demonstrated for the first time to be a driver of customer brand engagement, and hence is an important contribution to the literature on customer brand engagement.

These findings suggest that the impact of the experiential components on customer brand engagement is culture-specific and consideration should be given to the nature of the consumers and the context of the industry environment. This finding is consistent with the nature of customer engagement, which Brodie et al., (2011) state is a context-specific construct that requires examination in different settings. The differences illustrated in Australian and French contexts reflect the different cultural participants and emphasize the importance of customers and their interaction with the brand at the BME. These findings are likely a consequence of the variations in wine consumer culture, wine industry structure, and the nature of the wine brand (individual versus regional brands). The findings suggest a more ‘hands on’ or physical experience is required at French events, while Australians engage with a brand through a less physical event; a chance to take in wine information, experience the sensory components of food or music, or interact with others to create a social experience. This finding is reflective of the rapid development of French wineries that provide customers with their own wine making experiences (Anson, 2012; Viniv, 2014). However, given the preliminary nature of the findings, the recommendations should be considered tentative until further evidence is provided from a more comprehensive cultural study. 


\section{Managerial Implications}

The overarching managerial implication from this research is that BMEs may influence customer brand engagement and purchase intention, and therefore could form part of a winery's marketing strategy. Marketing managers and event organizers should take into consideration the nature of their consumers in planning BMEs that have the ability to facilitate customer brand engagement. The primary purpose of the event is to provide the customer with a meaningful avenue for interacting with the brand in order to develop a deeper and more meaningful brand connection.

In addition, this study presents interesting findings for managers of wine brands in Australia and France. Intensifying engagement in an Old World wine region (France) may require the utilization of different types of activities and strategies compared to those necessary to facilitate customer brand engagement in a New World wine region (Australia). This is of particular importance as practitioners in Old and New World wine producing markets look to each other for examples of innovative and effective practices; it is necessary to look at the underlying consumer profile, their attitude to the product and what they are likely to need from marketing activities, in particular BMEs. For Australian wineries it is crucial for managers to increase their understanding of engagement as reaching this leads to increased purchase intention. Providing a cognitive experience is particularly important in the Australian market, as the findings in this paper suggest a strong relationship with customer brand engagement. As a sensory product, wine offers the opportunity to also extend sensory experiences into other areas; this type of experience also facilitates customer brand engagement. Australian wineries should consider placing greater emphasis on cognitive and sensorial components of customer experience, while wine serves as one of the key constituents. It should be noted that respondents of this study were drawn from attendees of winery-hosted events, and therefore the results have 
use for managers in similar settings. While initial implications can be drawn for managers in different environmental settings, further investigation should occur before the results are generalized.

For French wineries, the traditional focus has been on the cultural and educational aspects of the wine experience, with wine brands not necessarily seeking to establish a long-term relationship with visitors (Faugère et al., 2013). This sentiment can certainly taint the overall interaction between winery staff and customers, often creating a feeling of 'distance' for the customer. However, there is room for improvement with the pragmatic experience of BMEs. French wineries are advised to implement BMEs with a strong pragmatic experience, as this was the sole experiential component found to facilitate brand engagement for French customers. Therefore, the design and execution of BMEs should reflect this perspective and provide an opportunity for customers to uniquely create their experiences by giving them the opportunity to engage in physical behaviors and actions during the event.

This paper has established the need to prompt managerial awareness of BMEs, and the particular experiential components required to target their customers and facilitate brand engagement. Wine customers in France seek a more dynamic relationship with wineries - for example blending their own wine, or creating their own labels. In contrast, Australian customers wish to acquire knowledge in oenology, and wineries should consider their further role in educating customers and building ongoing relationships with a brand via specific sensory experiences. The preliminary observations are consistent with theoretical notions concerning the enhancement of customer loyalty (Brodie et al., 2011), which reiterates that BMEs have strong potential to contribute to brand-related outcomes. It is argued that the creation of unique and memorable experiences through BMEs can have a favorable impact on brand purchase intention. 


\section{Limitations and Future Research}

This paper presents an initial attempt to define the impact of the five different experiential components of Brand Marketing Events on customer brand engagement. The interpretation of results are considered in light of various study limitations, in particular the differences in data collection methods between the two countries e.g. paper vs. online survey, data collected during event vs. after event. In addition, the findings remain limited as the cultural elements between the two study countries were not exhaustively explored. Replication and extension of the study in other countries and in other industries, such as retail, education and hospitality, would be useful to further understand the sociocultural impact of the findings.

A key difference in the understanding of a wine brand differs between Australian consumers and French consumers, with New World wines (Australia) promoting and organizing events around individual wine brands and Old World wines (France) around region and subregion brands. Further investigation of the impact of different levels of brands should be pursued in future research. For example, consideration should be given to whether the results would differ if conducted for the "chateaux" level of the brand in France and/or the region level in Australia (e.g. McLaren Vale wines).

This study purposefully selected branded wine events that contained several experiential components and represented a broad cross-section of the wine-related events held in South Australia and Bordeaux, France. However, future research could utilize an experimental design and/or investigate the impact of the nature of the event and the customer's perceived service quality or satisfaction with the event.

Although the model of BME experiences facilitating customer engagement holds across both samples in this study, the fact that four of the five hypotheses pertaining to the French sample are not supported is worthy of future investigation. In understanding the differences in 
consumer wine culture between Australia and France, it is recognized that French consumers are highly involved in wine, but this may actually foster a culture where they are less engaged with the specific wine brands. Future research should consider the boundaries conditions of wine involvement and also consider the nuances of this model for highly engaged and disengaged consumers.

Several study avenues remain as they are beyond the scope of this research: investigation of BMEs across various segments, including demographics such as income level, wine involvement, education and age could aid in further understanding viable customer groups to engage using BMEs. In addition, it is important to understand the interplay that exists between brand and region, and how this may create confusion and dilute the impact of BMEs in building the customers' perceptions of a wine region versus a particular brand. These themes are left for future exploration. Ultimately, the aim of this paper is to create BME benchmarks in the Australian and French wine sectors to enhance customer brand engagement and strengthen the existing links between wine customers and wine producers. 


\section{References}

Anderson, K. (2004), The world's wine markets: Globalization at work, Edward Elgar Publishing, Cheltenham, UK.

Anson, J. (2012), “Crushpad Bordeaux to open at Lynch Bages”, available at:

http://www.decanter.com/news/wine-news/529921/crushpad-bordeaux-to-open-at-lynchbages (accessed 12 November 2014).

Brakus, J.J., Schmitt, B.H., and Zarantonello, L. (2009), "Brand experience: what is it? How is it measured? Does it affect loyalty?” Journal of Marketing, Vol. 73 No. 3, pp. 52-68.

Brodie, R.J., Hollebeek, L.D., Jurić, B., and Ilić, A. (2011), “Customer Engagement: Conceptual Domain, Fundamental Propositions, and Implications for Research.” Journal of Service Research, Vol. 14 No. 3, pp. 252-271.

Brodie, R.J., Ilić, A., Jurić, B., and Hollebeek, L.D. (2013), “Consumer engagement in a virtual brand community: An exploratory analysis.” Journal of Business Research, Vol. 66 No. 1, pp. 105-114.

Bouzdine-Chameeva, T., Faugère, C., and Mora, P. (2015), “Branding winery tourism destination - Bordeaux case.” in Lee, K. (Ed.), Strategic Winery Tourism and Management, Apple Academic Press Inc., New Jersey.

Byrne, B.M. (2010), Structural Equation Modeling with AMOS: Basic Concepts, Applications, and Programming 2nd ed., Routledge Taylor \& Francis Group, New York. Calder, B.J., Isaac, M.S., and Malthouse, E.C. (2013), “Taking the Customer's Point-of-View: Engagement or Satisfaction?” Marketing Science Institute Working Paper, Report No. 13102. 
Calder, B.J., Malthouse, E.C., and Schaedel, U. (2009), “An experimental study of the relationship between online engagement and advertising effectiveness.” Journal of Interactive Marketing, Vol. 23 No. 4, pp. 321-331.

Chan, K.W., Yim, C.K., and Lam, S.S. (2010), “Is customer participation in value creation a double-edged sword? Evidence from professional financial services across cultures.” Journal of Marketing, Vol. 74, No. 3, pp. 48-64.

Chandler, J.D., and Lusch, R.F. (2015), "Service Systems: A Broadened Framework and Research Agenda on Value Propositions, Engagement, and Service Experience.” Journal of Service Research, Vol. 18 No. 1, pp. 6-22.

Chang, P., and Chieng, M. (2006), “Building consumer-brand relationship: A cross-cultural experiential view.” Psychology and Marketing, Vol. 23 No. 11, pp. 927-959.

Charters, S., Fountain, J., and Fish, N. (2009), “You Felt Like Lingering.” Journal of Travel Research. Vol. 48 No. 1, pp. 122-134.

Charters, S., and Ali-Knight, J. (2000), “Wine tourism-a thirst for knowledge?” International Journal of Wine Marketing, Vol. 12 No. 3, pp. 70-80.

Charters, S., and Pettigrew, S. (2005), “Is wine consumption an aesthetic experience?” Journal of Wine Research, Vol. 16 No. 2, pp. 121-136.

Close, A.G., Finney, Z.R., Lacey, R.Z., and Sneath, J.Z. (2006), “Engaging the consumer through event marketing: Linking attendees with the sponsor, community, and brand.” Journal of Advertising Research, Vol. 46 No. 4, pp. 420-433.

Crowther, P. (2010), “Marketing space: a conceptual framework for marketing events.” The Marketing Review, Vol. 10 No. 4, pp. 369-383. 
Crowther, P. (2011), “Marketing event outcomes: from tactical to strategic.” International Journal of Event and Festival Management, Vol. 2 No. 1, pp. 68-82.

Drengner, J., Gaus, H., and Jahn, S. (2008), “Does Flow Influence the Brand Image in Event Marketing?” Journal of Advertising Research, Vol. 48 No. 1, pp. 138-147.

Faugère, C., Bouzdine-Chameeva, T., Durrieu, F., and Pesme, J. (2013), “The Impact of Tourism Strategies and Regional Factors on Wine Tourism Performance: Bordeaux vs. Mendoza, Mainz, Florence, Porto and Cape Town.” Social Science Research Network Working Paper Series, Mendoza, Mainz, Florence, Porto and Cape Town. January 16, 2013.

Fornell, C., and Larcker, D.F. (1981), “Evaluating structural equation models with unobservable variables and measurement error.” Journal of Marketing Research, Vol. 18 No. 1, pp. 39-50.

FranceAgriMer. (2013), “The figures in the wine industry 2001/2011”, available at: http://www.franceagrimer.fr/filiere-vin-et-cidriculture/Vin/En-un-clic/Publications (accessed 12 November 2014).

Gentile, C., Spiller, N., and Noci, G. (2007), “How to Sustain the Customer Experience: An Overview of Experience Components that Co-create Value With the Customer.” European Management Journal, Vol. 25 No. 5, pp. 395-410.

Germov, J., and McIntyre, J. (2013), “The rise of Australia as a wine nation”, available at: http://theconversation.com/the-rise-of-australia-as-a-wine-nation-14875 (accessed 27 September 2015).

Getz, D. (2008), “Event tourism: Definition, evolution, and research.” Tourism Management, Vol. 29 No. 3, pp. 403-428. 
Grewal, D., Levy, M., and Kumar, V. (2009), “Customer experience management in retailing: an organizing framework.” Journal of Retailing, Vol. 85 No. 1, pp. 1-14.

Gupta, S. (2003), “Event Marketing: Issues and Challenges.” IIMB Management Review (Indian Institute of Management Bangalore), Vol. 15 No. 2, pp. 87-96.

Hair, J.F., Black, W.C., Babin, B.J, and Anderson, R.E. (2012), Multivariate Data Analysis, 7th ed., Pearson Education Limited, New Jersey.

Hall, C.M., Sharples, L., Cambourne, B., and Macionis, N. (2009), Wine tourism around the world, Routledge, New York.

Hall, J., Shaw, M., and Doole, I. (1997), “Cross-cultural analysis of wine consumption motivations.” International Journal of Wine Marketing, Vol. 9 No. 2, pp. 83-92.

Hoffman, D., Beverland, M., and Rasmussen, M. (2001), “The evolution of wine events in Australia and New Zealand: A proposed model.” International Journal of Wine Marketing, Vol. 13 No. 1, pp. 54-71.

Hollebeek, L.D. (2011a), “Demystifying customer brand engagement: Exploring the loyalty nexus.” Journal of Marketing Management, Vol. 27 No. 7-8, pp. 785-807.

Hollebeek, L.D. (2011b), “Exploring customer brand engagement: definition and themes.” Journal of Strategic Marketing, Vol. 19 No. 7, pp. 555-573.Hollebeek, L.D., Glynn, M.S., and Brodie, R.J. (2014), “Consumer Brand Engagement in Social Media: Conceptualization, Scale Development and Validation.” Journal of Interactive Marketing, Vol. 28 No. 2, pp. 149-165. 
Jaakkola, E. and Alexander, M. (2014), “The Role of Customer Engagement Behavior in Value Co-Creation A Service System Perspective.” Journal of Service Research, Vol. 17 No. 3, pp. 247-261.

Jordan, R., Zidda, P., and Lockshin, L. (2007), “Behind the Australian wine industry's success: does environment matter?” International Journal of Wine Business Research, Vol. 19 No. 1, pp. 14-32.

Karlsson, P., and Karlsson, B. (2015), "Which Countries Produce And Consume The Most Wine?” available at: http://www.forbes.com/sites/karlsson/2015/02/16/france-is-the-biggestwine-producer-in-2014-but-less-wine-is-made-and-drunk-in-europe/ (accesesed 27 September 2015).

Klaus, P., and Maklan, S. (2013), “Towards a better measure of customer experience”. International Journal of Market Research, Vol. 55 No. 2, pp. 227-246.

Kline, R.B. (2005), Principles and practice of structural equation modeling, 2nd ed., The Guilford Press, New York.

Leischnig, A., Schwertfeger, M., and Geigenmueller, A. (2011), “Do shopping events promote retail brands?” International Journal of Retail \& Distribution Management, Vol 39 No. 8, pp. 619-634.

Lereboullet, A.L., Beltrando, G., and Bardsley, D.K. (2013), “Socio-ecological adaptation to climate change: A comparative case study from the Mediterranean wine industry in France and Australia.” Agriculture, ecosystems \& environment, Vol. 164, pp. 273-285. 
Lockshin, L., Quester, P. and Spawton, T. (2001), “Segmentation by involvement or nationality for global retailing: A cross-national comparative study of wine shopping behaviours.” Journal of Wine Research, Vol. 12 No. 3, pp. 223-236.

Martensen, A., Gronholdt, L., Bendtsen, L., and Jensen, M.J. (2007), “Application of a Model for the Effectiveness of Event Marketing.” Journal of Advertising Research, Vol. 47 No. 3, pp. 283-301.

Mau, G., Weihe, K., and Silberer, G. (2006), “Attitudinal Effects of Event-Marketing and Event-Sponsorship: A Comparison.” 35th EMAC Annual Conference Proceedings, Athens, Greece.

Mollen, A., and Wilson, H. (2010), “Engagement, telepresence and interactivity in online consumer experience: Reconciling scholastic and managerial perspectives.” Journal of Business Research, Vol. 63 No. 9, pp. 919-925.

Mora, P., and Moscarola, J. (2010), "Representations of the emotions associated with a wine purchasing or consumption experience.” International Journal of Consumer Studies, Vol. 34 No. 6, pp. 674-683.

Neuman, W.L. (2006), Social Research Methods: Qualitative and Quantitative Approaches, Pearson Education Inc., Boston.

Ogbeide, O. A., Stringer, R., and Ford, C. (2014), “Are Australian wine consumers willing to pay for the expert service of wine retailers?” Journal of Wine Research, Vol. 25 No. 3, pp. 189-208.

Office International de la Vigne et du Vin (OIV). (2014), “The wine market: developments and trends”, available at: 
http://www.oiv.int/oiv/info/en_press_conference_may_2014?lang=en (accessed 27

September 2015).

Overby, J. W., Gardial, S.F., and Woodruff, R.B. (2004), “French versus American consumers attachment of value to a product in a common consumption context: A crossnational comparison.” Journal of the Academy of Marketing Science, Vol. 32 No. 4, pp. 437460.

Packer, J., and Ballantyne, R. (2004), “Is educational leisure a contradiction in terms? Exploring the synergy of education and entertainment.” Annals of Leisure Research, Vol. 7 No. 1, pp. 54-71.

Palmer, A. (2010), “Customer experience management: a critical review of an emerging idea.” Journal of Services Marketing, Vol. 24 No. 3, pp. 196-208.

Peter, J.P. (1981), “Construct validity: a review of basic issues and marketing practices.” Journal of Marketing Research, Vol. 18 No. 3, pp. 133-145.

Pine, B.J., and Gilmore, J.H. (1998), “Welcome to the experience economy.” Harvard Business Review, Vol. 76, pp. 97-105.

Plewa, C., Conduit, J., Quester, P., and Johnson, C. (2015), "The Impact of Corporate Volunteering on CSR Image: A Consumer Perspective." Journal of Business Ethics, Vol. 127 No. 3, pp. 643-659.

Rasmussen, M., and Lockshin, L. (1999), "Wine Choice Behaviour: The Effect of Regional Branding." International Journal of Wine Marketing, Vol. 11 No. 1, pp. 36-46.

Randall, D.M., and Gibson, A.M. (1990), “Methodology in business ethics research: A review and critical assessment.” Journal of Business Ethics, Vol. 9 No. 6, pp. 457-471. 
Rowe, K.(2002), “The Measurement of Latent and Composite Variables from Multiple Items or Indicators: Applications in Performance Indicator Systems." Proceedings of the Royal Melbourne Institute of Technology Seminar Series, Melbourne.

Schmitt, B. (1999), “Experiential Marketing.” Journal of Marketing Management, Vol. 15 No. 1, pp. 53-67.

So, K.K.F., King, C., and Sparks, B.A. (2014a), “Customer Engagement With Tourism Brands: Scale Development and Validation.” Journal of Hospitality and Tourism Research, Vol. 38 No. 3, pp. 304-329.

So, K.K.F., King, C., Sparks, B.A., and Wang, Y. (2014b), "The Role of Customer Engagement in Building Consumer Loyalty to Tourism Brands." Journal of Travel Research: DOI 0047287514541008.

Summerfield, M. (2013), "Wine drinking culture in France: a national myth or a modern passion?” Journal of Wine Research, Vol. 24 No. 1, pp. 81-82.

Sweeney, J.C., and Soutar, G.N. (2001), “Consumer perceived value: The development of a multiple item scale.” Journal of Retailing, Vol. 77 No. 2, pp. 203-220.

Vargo, S.L., and Lusch, R.F. (2004), “Evolving to a New Dominant Logic for Marketing.” Journal of Marketing, Vol. 68 No. 1, pp 1-17.

Vargo, S.L., and Lusch, R.F. (2008), "Service-dominant logic: continuing the evolution.” Journal of the Academy of Marketing Science, Vol. 36 No. 1, pp. 1-10.

Velikova N., Charters S., Bouzdine-Chameeva T., Fountian J., and Ritchie C. (2015), “Seriously Pink: A Cross-Cultural Examination of the Perceived Image of Rosé Wine.” International Journal of Wine Business Research, forthcoming Vol. 27 No. 4. 
Viniv. (2014), “Make Wine at Viniv”, available at: http://www.vinivwine.com/en (accessed 12 November 2014).

Vivek, S., Beatty, S., Dalela, V., and Morgan, R. (2014), “A Generalized Multidimensional Scale for Measuring Customer Engagement.” Journal of Marketing Theory and Practice, Vol. 22 No. 4, pp. 401-420.

Vivek, S., Beatty, S., and Morgan, R. (2012), “Customer Engagement: Exploring Customer Relationships Beyond Purchase.” Journal of Marketing Theory and Practice, Vol. 20 No. 2, pp. 122-146.

Weihe, K., Mau, G., and Silberer, G. (2006), “How do marketing-events work? Marketingevents and brand attitudes.” In Diehl, S., and Terlutter, R. (Eds.), International Advertising and Communication: Current insights and empirical findings, Springer, Wiesbaden, pp. 199216.

Whelan, S.,and Wohlfeil, M. (2006), “Communicating brands through engagement with lived experiences.” Journal of Brand Management, Vol. 13 No. 4-5, pp. 313-329.

Winebiz. (2013), “Wine Industry Statistics: Highlights of 2011-2012”, available at: http://www.winebiz.com.au/statistics/ (accessed 30 January 2014).Wohlfeil, M., and Whelan, S. (2006), “Consumer Motivations to Participate in Event-Marketing Strategies.” Journal of Marketing Management, Vol. 22 No. 5-6, pp. 643-669.

Woisetschläger, D.M., and Michaelis, M. (2012), “Sponsorship congruence and brand image: A pre-post event analysis.” European Journal of Marketing, Vol. 46 No. 3-4, pp. 509-523.

Wood, E.H. (2009), “Evaluating Event Marketing: Experience or Outcome?” Journal of Promotion Management, Vol. 15 No. 1, pp. 247-268. 
Yuan, Y., and Wu, C.K. (2008), "Relationships among experiential marketing, experiential value, and customer satisfaction.” Journal of Hospitality \& Tourism Research, Vol. 32 No. 3, pp. 387-410.

Zhang, J., Beatty, S.E., and Mothersbaugh, D. (2010), “A CIT investigation of other customers' influence in services” Journal of Services Marketing, Vol. 24 No. 5, pp. 389-399. 
Figure 1: Conceptual Framework and Hypotheses

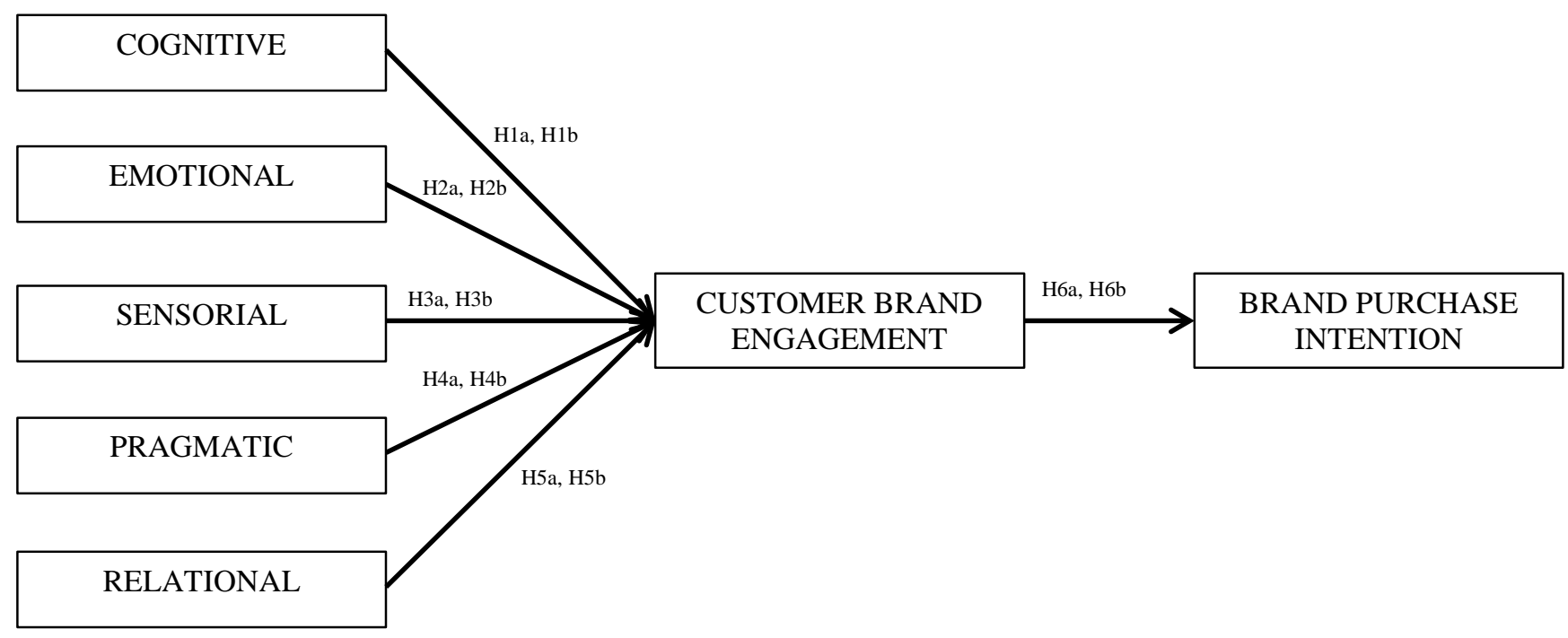


Table 1: Experiential Components within a BME

\title{
Experiential
}

Component

\author{
Definition and Example
}

Cognitive Experiences that stimulate thought or conscious mental processes.

Example: Wine education sessions, food/wine pairing, winery tours

Emotional Experiences that evoke an affective response or relation (with a company, brand or products), by targeting moods, feelings and/or emotions

Example: Winery picnic, Coriole poetry appreciation events.

Sensorial Experiences that aim to provide positive sensory stimulation, addressing sight, hearing, touch, taste and/or smell.

Example: Wine and food event, music event.

Pragmatic Experiences that involve physical action and the act of 'doing something'. Example: 'Make your own wine blend' events.

Relational Experiences that provide social context, relationships with others, or expression of one's 'ideal self'.

Example: Events that project a 'wine enthusiast' image, or means of entering an in-group of wine connoisseurs.

Source: Definitions adapted from Gentile et al. (2007) 
Table 2: Summary of Events

\section{Wine brand Events held}

\begin{tabular}{ll}
\hline Australia & \\
Brand A & 3 Concerts at Winery \\
Brand B & Lunch and Dinner with the winemaker events \\
Brand C & Picnic at the winery (\& live music) \\
Brand D & Silent Auction with food and wine \\
Brand E & Dinner with the winemakers \\
Brand F & New wine launch (with lunch) \\
France & \\
Brand G & Chateau Event \\
Brand H & Concert \\
Brand I & Conference (wine education) \\
Brand J & Degustation \\
Brand K & Exposition \\
Brand L & Restaurant \\
\hline
\end{tabular}


Table 3: Reliability and Validity of Multi-Item Variables in Questionnaire

\begin{tabular}{|c|c|c|c|c|c|c|c|}
\hline Scale & Item & Mean & $\begin{array}{l}\text { Standard } \\
\text { Deviation }\end{array}$ & $\begin{array}{l}\text { Cronbach } \\
\text { Alpha }\end{array}$ & $\begin{array}{l}\text { Construct } \\
\text { Reliability }\end{array}$ & $\begin{array}{l}\text { Variance } \\
\text { Extracted }\end{array}$ & $\begin{array}{l}\text { Highest } \\
\text { Squared } \\
\text { Correlation }\end{array}$ \\
\hline \multirow{2}{*}{$\begin{array}{l}\text { Cognitive } \\
\text { Experience }\end{array}$} & $\begin{array}{l}\text { This event tried to } \\
\text { intrigue me }\end{array}$ & 4.64 & 1.74 & \multirow{2}{*}{0.71} & \multirow{2}{*}{0.75} & \multirow{2}{*}{0.61} & \multirow{2}{*}{0.23} \\
\hline & $\begin{array}{c}\text { This event tried to } \\
\text { stimulate my curiosity }\end{array}$ & 5.19 & 1.53 & & & & \\
\hline \multirow[b]{2}{*}{$\begin{array}{l}\text { Emotional } \\
\text { Experience }\end{array}$} & $\begin{array}{l}\text { This event tried to } \\
\text { arouse feelings in me }\end{array}$ & 4.82 & 1.59 & \multirow[b]{2}{*}{0.87} & \multirow[b]{2}{*}{0.85} & \multirow[b]{2}{*}{0.74} & \multirow[b]{2}{*}{0.30} \\
\hline & $\begin{array}{l}\text { This event induced } \\
\text { feelings and } \\
\text { sentiments }\end{array}$ & 4.92 & 1.54 & & & & \\
\hline \multirow{3}{*}{$\begin{array}{l}\text { Sensorial } \\
\text { Experience }\end{array}$} & \begin{tabular}{|} 
This event was \\
focused on creating a \\
sensory experience
\end{tabular} & 5.59 & 1.52 & \multirow{3}{*}{0.90} & \multirow{3}{*}{0.90} & \multirow{3}{*}{0.75} & \multirow{3}{*}{0.23} \\
\hline & $\begin{array}{l}\text { This event tried to } \\
\text { excite my senses }\end{array}$ & 5.71 & 1.43 & & & & \\
\hline & $\begin{array}{l}\text { This event provided } \\
\text { sensory enjoyment }\end{array}$ & 5.85 & 1.32 & & & & \\
\hline \multirow{3}{*}{$\begin{array}{l}\text { Pragmatic } \\
\text { Experience }\end{array}$} & $\begin{array}{c}\text { I engaged in physical } \\
\text { actions and behaviors } \\
\text { when I attended this } \\
\text { event }\end{array}$ & 4.22 & 1.86 & \multirow{3}{*}{0.78} & \multirow{3}{*}{0.76} & \multirow{3}{*}{0.52} & \multirow{3}{*}{0.14} \\
\hline & $\begin{array}{c}\text { This event was action } \\
\text { oriented }\end{array}$ & 3.46 & 1.74 & & & & \\
\hline & $\begin{array}{l}\text { This event involved } \\
\text { physical experiences }\end{array}$ & 3.88 & 1.83 & & & & \\
\hline \multirow{3}{*}{$\begin{array}{l}\text { Relational } \\
\text { Experience }\end{array}$} & $\begin{array}{l}\text { Attending this event } \\
\text { improved the way I } \\
\text { am perceived }\end{array}$ & 3.41 & 1.60 & \multirow{3}{*}{0.93} & \multirow{3}{*}{0.90} & \multirow{3}{*}{0.75} & \multirow{3}{*}{0.12} \\
\hline & $\begin{array}{l}\text { Attending this event } \\
\text { gave me social } \\
\text { approval }\end{array}$ & 3.86 & 1.63 & & & & \\
\hline & $\begin{array}{l}\text { Attending this event } \\
\text { created a favorable } \\
\text { perception of me } \\
\text { among other people }\end{array}$ & 3.78 & 1.57 & & & & \\
\hline \multirow{2}{*}{$\begin{array}{l}\text { Brand } \\
\text { Purchase } \\
\text { Intention }\end{array}$} & $\begin{array}{l}\text { I intend to purchase } \\
\text { (wine brand) wines in } \\
\text { the near future }\end{array}$ & 5.84 & 1.41 & \multirow[b]{2}{*}{0.87} & \multirow[b]{2}{*}{0.81} & \multirow[b]{2}{*}{0.68} & \multirow[b]{2}{*}{0.43} \\
\hline & \begin{tabular}{|c} 
There is a high \\
probability I would \\
purchase (wine brand) \\
wines
\end{tabular} & 5.12 & 1.73 & & & & \\
\hline
\end{tabular}




\begin{tabular}{|c|c|c|c|c|c|c|c|}
\hline & $\begin{array}{c}\text { Brand Engagement } \\
\text { Overall }\end{array}$ & & & 0.88 & 0.90 & 0.75 & 0.43 \\
\hline & $\begin{array}{l}\text { Brand Attention } \\
\text { Aggregate:* }\end{array}$ & 5.45 & 1.29 & & & & \\
\hline & $\begin{array}{c}\text { I like learning about X } \\
\text { Winery }\end{array}$ & 5.77 & 1.28 & & & & \\
\hline & $\begin{array}{c}\text { I pay a lot of attention } \\
\text { to anything about } X \\
\text { Winery }\end{array}$ & 5.44 & 1.44 & & & & \\
\hline & $\begin{array}{c}\text { Anything related to X } \\
\text { Winery grabs my } \\
\text { attention }\end{array}$ & 5.10 & 1.58 & & & & \\
\hline & $\begin{array}{c}\text { I concentrate a lot on } \\
\text { X Winery }\end{array}$ & 4.30 & 1.76 & & & & \\
\hline & $\begin{array}{l}\text { Brand Enthusiasm } \\
\text { Aggregate: * }\end{array}$ & 5.21 & 1.28 & & & & \\
\hline & $\begin{array}{l}\text { I am enthusiastic } \\
\text { about X Winery }\end{array}$ & 5.38 & 1.45 & & & & \\
\hline & $\begin{array}{c}\text { I feel excited about } \mathrm{X} \\
\text { Winery }\end{array}$ & 4.68 & 1.67 & & & & \\
\hline Engagement & $\begin{array}{c}\text { To me, drinking X } \\
\text { wines is worthwhile }\end{array}$ & 5.63 & 1.34 & & & & \\
\hline & $\begin{array}{c}\text { Brand Interaction } \\
\text { Aggregate:* }\end{array}$ & 3.91 & 1.33 & & & & \\
\hline & $\begin{array}{c}\text { I have a high level of } \\
\text { interaction with X } \\
\text { Winery }\end{array}$ & 3.98 & 1.74 & & & & \\
\hline & $\begin{array}{c}\text { I like to receive } \\
\text { information about } X \\
\text { Winery through } \\
\text { newsletters/ online } \\
\text { subscriptions }\end{array}$ & 4.22 & 1.86 & & & & \\
\hline & \begin{tabular}{|c|} 
I enjoy discussing $X$ \\
Winery with others \\
through online \\
forums/ brand \\
communities/ social \\
media (e.g. Facebook, \\
Twitter)
\end{tabular} & 3.32 & 1.84 & & & & \\
\hline & $\begin{array}{l}\text { I spend a lot of time } \\
\text { drinking } X \text { wines, } \\
\text { compared to other } \\
\text { wines }\end{array}$ & 4.08 & 1.85 & & & & \\
\hline
\end{tabular}

* Aggregate measures were used in CFA analysis. 
Table 4: Hypothesis Results Summary - Australian Customers

\begin{tabular}{lcccc}
\hline Hypothesis: & $\begin{array}{c}\text { Standardized } \\
\text { Estimates }\end{array}$ & $\begin{array}{c}\text { Critical } \\
\text { Ratio }\end{array}$ & P & $\begin{array}{c}\text { Supported/ } \\
\text { Not Supported }\end{array}$ \\
\hline $\begin{array}{l}\text { H1a - Cognitive experience -- } \\
\text { customer brand engagement }\end{array}$ & 0.29 & 4.46 & 0.00 & Supported \\
\hline $\begin{array}{l}\text { H2a - Emotional experience -- }> \\
\text { customer brand engagement }\end{array}$ & 0.03 & 0.49 & 0.62 & Not supported \\
\hline $\begin{array}{l}\text { H3a - Sensorial experience -- }> \\
\text { customer brand engagement }\end{array}$ & 0.20 & 2.87 & 0.04 & Supported \\
\hline $\begin{array}{l}\text { H4a - Pragmatic experience -- }> \\
\text { customer brand engagement }\end{array}$ & -0.01 & -0.24 & 0.81 & Not supported \\
\hline $\begin{array}{l}\text { H5a - Relational experience -- }> \\
\text { customer brand engagement }\end{array}$ & 0.12 & 2.11 & 0.03 & Supported \\
\hline $\begin{array}{l}\text { H6a - customer brand engagement } \\
<-->\text { purchase intention }\end{array}$ & 0.74 & 18.30 & 0.00 & Supported \\
\hline
\end{tabular}


Table 5: Hypothesis Results Summary - French Customers

\begin{tabular}{lcccc}
\hline Hypothesis: & $\begin{array}{c}\text { Standardized } \\
\text { Estimates }\end{array}$ & $\begin{array}{c}\text { Critical } \\
\text { Ratio }\end{array}$ & P & $\begin{array}{c}\text { Supported/ } \\
\text { Not Supported }\end{array}$ \\
\hline $\begin{array}{l}\text { H1b - Cognitive experience -- } \\
\text { customer brand engagement }\end{array}$ & 0.03 & 0.32 & 0.75 & Not supported \\
\hline $\begin{array}{l}\text { H2b - Emotional experience -- }> \\
\text { customer brand engagement }\end{array}$ & 0.04 & 0.50 & 0.62 & Not supported \\
\hline $\begin{array}{l}\text { H3b - Sensorial experience -- }> \\
\text { customer brand engagement }\end{array}$ & -0.02 & -0.27 & 0.79 & Not supported \\
\hline $\begin{array}{l}\text { H4b - Pragmatic experience -- }> \\
\text { customer brand engagement }\end{array}$ & 0.28 & 3.70 & 0.00 & Supported \\
\hline $\begin{array}{l}\text { H5b - Relational experience -- }> \\
\text { customer brand engagement }\end{array}$ & -0.05 & -0.61 & 0.54 & Not supported \\
\hline $\begin{array}{l}\text { H6b - customer brand engagement } \\
<-->\text { purchase intention }\end{array}$ & 0.42 & 6.06 & 0.00 & Supported \\
\hline
\end{tabular}


Table 6: Critical Ratio for Difference between Parameters

\begin{tabular}{lcccc}
\hline Hypothesis: & $\begin{array}{c}\text { Australian } \\
\text { Standardized } \\
\text { Estimates }\end{array}$ & $\begin{array}{c}\text { French } \\
\text { Standardized } \\
\text { Estimates }\end{array}$ & $\begin{array}{c}\text { Critical } \\
\text { Ratio }\end{array}$ & $\begin{array}{c}\text { Supported/ } \\
\text { Not Supported }\end{array}$ \\
\hline $\begin{array}{l}\text { H1b - Cognitive experience } \\
\text {--> customer brand engagement }\end{array}$ & 0.29 & 0.03 & -2.92 & Supported \\
\hline $\begin{array}{l}\text { H2b - Emotional experience } \\
-->\text { customer brand engagement }\end{array}$ & 0.03 & 0.04 & -0.01 & Not Supported \\
\hline $\begin{array}{l}\text { H3b - Sensorial experience } \\
-->\text { customer brand engagement }\end{array}$ & 0.20 & -0.02 & -2.17 & Supported \\
\hline $\begin{array}{l}\text { H4b - Pragmatic experience } \\
-->\text { customer brand engagement }\end{array}$ & -0.01 & 0.28 & 2.76 & Supported \\
\hline $\begin{array}{l}\text { H5b - Relational experience } \\
-->\text { customer brand engagement }\end{array}$ & 0.12 & -0.05 & -1.90 & Not Supported \\
\hline $\begin{array}{l}\text { H6b - Customer brand } \\
\text { engagement --> purchase } \\
\text { intention }\end{array}$ & 0.74 & 0.42 & -2.43 & Supported \\
\hline
\end{tabular}

